\title{
INVESTIGATING THE KEY DRIVERS OF GOVERNMENT DEBT IN SOUTH AFRICA: A POST-APARTHEID ANALYSIS
}

\section{Lerato Mothibi}

North-West University

E-mail: Lerato.Mothibi@nwu.ac.za

Orcid No: 0000-0002-2418-8314

\section{Precious Mncayi}

North-West University

E-mail: Precious.Mncayi@nwu.ac.za

Orcid: 0000-0001-5375-0911

\section{-Abstract -}

Over the years, the world has experienced increased and persistent levels of high government debts. This situation has been fuelled by the sluggish economic growth rates and weak revenue collections, particularly in the sub-Saharan region. Using the auto-distributive lag (ARDL) model, the study investigates the key drivers of government debt in South Africa from 1994 to 2017. Findings of this study revealed that there is long-run relationship between government debt and government expenditure, real GDP, inflation and real interest rates, with government expenditure, real GDP and interest rates being the key drivers of government debt in South Africa. Government debt has had a negative impact on economic growth and inflation. In the short run, there are no significant interactions between inflation, real interest rates and government debt. To reduce government debt, the South African government should lean towards improving its productive capacity, controlling interest rates and eliminating non-productive expenditure. Factors such as bailout spending on non-performing and problematic state entities may be avoided by opening for competition to ease the burden off the state as a sole or main funder.

Keywords: Government debt, government spending, economic performance, indebted countries, South Africa

JEL classification: E62; H60 H11; H30; H50

\section{Cite (APA)}

Mothibi, L , Mncayi, P . (2019). Investigating The Key Drivers of Government Debt in South Africa: A Post-Apartheid Analysis. International Journal of eBusiness and eGovernment Studies, 11 (1), 16-33 . DOI: 10.34111/ijebeg.20191112 


\section{INTRODUCTION}

One of the most prominent global macroeconomic developments in recent years has been the upsurge and perseverance of large deficits and government debt. These developments have elevated fears regarding debt sustainability with the potential consequences of debt monetisation that initiates inflation and austerity measures that bring about extensive economic costs (Pirtea, Nicolescu \& Mota, 2013), making countries susceptible to economic crises (Mendoza \& Oviedo, 2004). Indeed, history reveals that over-borrowing was one of the underlying factors to both the 2008/09 global financial crisis and the Eurozone debt crisis (World Economic Forum, 2014).

In the case of sub-Saharan Africa, irresponsible borrowing has been recognised as one of the region's major challenges (Sambira, 2015). Since 2013, the stance on the region's debt sustainability has declined considerably (Battaile, Hernandez \& Norambuena, 2015). More specifically, there has been a concern that many countries in the sub-Saharan region lack fiscal discipline, one of the main contributors to the region's growing government debt. In just four years, from 2014 to 2017, the government debt to GDP ratio had risen to 45 percent from 32.2 percent (Van Cauwenbergh \& Laleman, 2018). A further observation is that a significant portion of the debt is often used to finance surging current expenditures such as public sector wage bills instead of capital expenditure, and this is evidenced by the lack of infrastructural development in the region. At the same time, various governments have assumed liabilities acquired by state-owned enterprises (SOEs).

South Africa is not unique to this situation, as the debt burden is seen as one of the country's key challenges (Vollgraaff \& Cohen, 2017). From the beginning of 2008, government debt has been on a persistent increase (Mellet, 2012), surpassing 50 percent of GDP in 2017 (National Treasury, 2018). By the second quarter of 2018, the country's debt per capita remained at R48 942, which is considerably higher than the average of countries with similar economic standing (Brandmeir, Grimm, Heise \& Holzhausen, 2017). Moreover, the majority of government's contingent liabilities have been mostly accounted for by inefficient state-owned entities (Budget Review, 2018), which have posed a major risk to the fiscus. Even though literature supports the fact that a growing economy determines an economy's ability to repay its debt (Perkins, Radelet \& Lindauer, 2006), the country has been growing at very low rates, and has faced persistent challenges of inequality, poverty and unemployment. High levels of government 
debt, especially on non-productive spending, are likely to be deleterious for growth and development (Shah, 2007), and can be very harmful as costs used to service the debts can drain resources that could have been used elsewhere. In the case of South Africa, an average of 13.8 per cent of revenue will be used for debt service over 2018 and 2020 (National Treasury, 2018), which again represents resources that could have been used in productive activities. In our understanding, to tackle the country's debt issues, there should be a thorough investigation of the determinants of this continually growing debt, and therefore the need for this study. As such, this study therefore has an objective of investigating factors that have contributed to the growth of government debt in South Africa since the beginning of democracy. The organisation of the paper is as follows. The next section discusses the literature on government debt and its known determinants. The section will further provide empirical studies carried out on the topic. The methodology, results and discussions are reported in section 3, and section 4 contains the conclusions and recommendations.

\section{LITERATURE REVIEW}

\subsection{Theoretical framework on government debt}

Government debt refers to the total amount of government fixed-term contractual responsibilities to others payable on a certain date (World Bank, 2013). According to Fall, Hoeller, Fournier and Bloch (2015), research on government debt sustainability levels in developing countries tends to confine debt thresholds to approximately 40 to 50 percent of GDP, subject to revenue raising abilities, growth prospects and the nature of fiscal threats confronting the country. This suggests that government debt-to-GDP ratios exceeding the threshold are a cause for concern.

Standard economic literature proposes the implementation of a countercyclical fiscal policy during economic downturns and increases in government debt, and reducing it during economic expansions (Barro, 1979). The Keynesian school of thought therefore justified increased government debt as a way of stabilising the economy, which implied that a government has to always have some form of debt (Keynes, 1937). This principle received some attention from political researcher, Lorenz von Stein, who argued that "A government without government debt is either doing too little for its future, or asking too much from its present" (von Stein, 1871:666). On the contrary, the Classicals were of the view that government debt would have some negative impact on the economy, as such 
spending to them was unproductive and wasteful (Smith, 1776). Equally so, the Neoclassicals criticised government indebtedness due to the crowding-out effects it has on investments, interest-sensitive durable consumption expenditure and consequently indirectly reducing consumption spending through a wealth effect (Friedman, 1978). In periods where revenue is not enough to cover spending, governments are forced to finance this shortfall through several financing options, including borrowing. The choice to seek finance domestically or externally will be based on the costs and risks associated with each option (Ellis \& Schansberg, 1999). In particular, the decision to finance spending through borrowing acquires follow-up costs that necessitate interest and principal payments due in future fiscal years (Holtfrerich, Feld \& Heun, 2016), and over time the borrowings will add to the public debt cost. Even though from a national perspective borrowing is justified and as such can play an important role in facilitating economic progress (Perkins et al., 2006), too much borrowing can create economic problems, particularly if growth and revenues fail to produce the resources needed to repay the debt (Van Cauwenbergh \& Laleman, 2018).

\subsection{Drivers of government debt}

Existing literature shows that government debt is primarily influenced by a combination of macroeconomic, socio-economic, institutional and structural factors. However, it is often unclear whether government debt is boosted by exogenous or endogenous factors (Holtfrerich et al., 2016).

Economic growth has a major influence on government debt. Since GDP measures an economy's ability to repay debt, a larger productive capacity and resultant income imply a greater ability to repay debt (Perkins et al., 2006). Therefore, low economic growth accompanied by weak revenue collections (which can stem from low tax base) will imply less fiscal revenues, consequently forcing government to use debt to finance spending (Van Cauwenbergh \& Laleman, 2018; Holtfrerich et al., 2016).

Similarly, a growing fiscal deficit forms a major part of the increase in the ratio of public debt (Belguith \& Omrane, 2017). The deficit of each year is added to the previous year's debt stock (Gruber, 2011), and therefore the stock of government debt becomes greater when the deficit increases, signifying higher interest payments.

The credibility of monetary and fiscal policy is likewise one of the important factors that determine the level of government debt. If the credibility of a 
country's policies is deemed to be uncertain, debt securities will be sold, which often puts an upward pressure on interest rates. This will eventually raise the cost of government borrowing. This increased cost of financing raises government debt because of increased interest payments (OECD, 2017). Consequently, a higher government debt level results than it would have been when interest rates were lower (Fourie \& Burger, 2010). Inflation is yet another factor that affects government debt through higher nominal interest payment (Afonso, 2003). In fact, Reinhart and Rogoff (2010) found that higher debt levels were linked to significantly higher levels of inflation in emerging market economies. However, Abbas et al. (2013) maintain that higher inflation essentially supports government debt reduction by lowering the real value of government debt.

Political factors are among other factors that may deviate fiscal outcomes from the optimal level, especially in emerging and developing economies (Natalia, 2006). In particular, political instability may fuel a country's deficit, and Henisz (2000) argues that this is possible through market uncertainties regarding the country's prospect to pay its debt and the quality of political institutions. As the magnitude of government debt surges, there are insecurities about policies that the government will use in order to meet its debt servicing obligations, with adverse effects on investment (Clements et al., 2003). Currency fluctuations also have an adverse effect on government debt, particularly on debt denominated in foreign currencies. According to Fourie and Burger (2010), if the domestic currency depreciates against the currency in which loans were borrowed, it means that the foreign debt has increased, which, in turn, raises the real debt burden (Holtfrerich et al., 2016). This debt-exchange rate channel can also be linked to terms of trade, with adverse effects for countries that are heavily dependent on primary exports, since these exports are vulnerable to shocks (Van Cauwenbergh \& Laleman, 2018).

Demographic factors such as population also put pressure on government debt by influencing spending, especially if the spending structure is skewed by a large share of current spending (OECD, 2017). According to Ellis and Schansberg (1999), contrary to an increased elderly population, an increase in younger age population is linked to increased spending and essentially more debt financing. This is especially true if the government has limited fiscal revenues, with high unemployment and numbers of individuals enrolled in social assistance (Kalaji \& Vokshi, 2015).

\subsection{Empirical overview}


The link between government debt and various economic factors has been investigated by various studies. In a study that investigated the influence of political fragmentation on government debt using data on 92 advanced and developing countries between 1975 and 2015, Crivelli et al. (2016) found strong evidence showing that political fragmentation plays a prominent role in explaining government debt dynamics. The effects were stronger in economies where corruption is perceived to be high. On the contrary, Ellis and Schansberg (1999) found that political variables were largely irrelevant to the accumulation of government debt.

Natalia (2006) studied the influence of economic and political factors on the level of government debt in 14 emerging countries. The study found that GDP per capita, growth rate of output, change in output gap, inflation, unemployment and real interest rate to be significant in explaining the level of government debt. In their study, Kumar and Woo (2010) discovered that, on average, a 10 percent increase in the debt-to-GDP ratio is connected to a 0.2 percent decline in real per capita GDP. Pirtea et al. (2013) found that real interest rates on government bonds, exchange rate and GDP growth rate remained a significant determinant of government debt in Romania between 2000 and 2011. Belguith and Omrane (2017) found similar results in a study that investigated the macroeconomic determinants of public debt growth in Tunisia between 1986 and 2015. They found that real interest rate, budget deficit and trade openness increased Tunisia's government debt during the specified period.

In an econometric investigation of the macroeconomic determinant of government debt in 46 countries for the period 1980 to 2009, Swamy (2015) found that real GDP growth, foreign direct investment (FDIs), government expenditure, inflation and population growth have negative effects on government debt. However, gross fixed capital formation, final consumption expenditure, and trade openness had positive effects on debt. In Albania, Kalaja and Vokshi (2015) found demographic factors, including unemployment, aging rate and pension schemes associated with ever-growing sovereign debt levels in the country. While Akitoby et al. (2014) found that inflation supports government debt reduction by lowering the real value of government debt, Forslund et al. (2011) found no statistical significance on the variable on the composition of government debt.

\section{METHODOLOGY}

\subsection{Study design}


The study makes use of annual data obtained from the South African Reserve Bank (SARB) and world development indicators (WDIs) from the period 1994 to 2017. All variables utilised in this study are transformed to their natural logarithm form. The variables specified include total loan debt of national government as a percentage of GDP, which is the dependent variable (GD), followed by the independent variables, i.e. gross domestic product per capita (GDP), national government expenditure as a percentage of GDP (GEXP), real interest rate (RINT), and inflation rate (CPI). For this reason, the quantitative research design was deemed fit and suitable for the study.

\subsection{Model specification}

The study makes use of the auto distributive lag (ARDL) model developed by Pesaran et al. (2001). The ARDL model has a number of advantages compared to other cointegration methodologies, such as the Johansen and Juselius (1990) cointegration technique. Firstly, the ARDL technique allows for variables to be integrated at either order I(0), I(1) or jointly at I(0) and I(1) (Habanabakize et al., 2017). Secondly, potential issues of endogeneity reflected in the explanatory variables are effectively rectified through the ARDL technique (Brini et al., 2015). Thirdly, the ARDL technique allows for the simultaneous use of different numbers of optimal lags for the variables (Kharusi \& Ada, 2018). Lastly, the ARDL techniques allow researchers to use a small sample size, such as the study of Kharusi and Ada (2018), which utilised a sample of 25 observations from 1990 to 2015. It is for these reasons that the ARDL techniques are used for its favourable properties. In order to determine the key drivers of government debt in South Africa, the following ARDL model is specified:

$$
\begin{aligned}
& \Delta L G D_{t}=\alpha_{0}+\sum_{i=1}^{n} \beta_{1 i} \Delta L G D_{t-i}+\sum_{i=1}^{n} \beta_{2 i} \Delta L G E X P_{t-i}+\sum_{i=1}^{n} \beta_{3 i} \Delta G D P_{t-i}+\sum_{i=1}^{n} \beta_{4 i} \Delta L R I N T_{t-i}+ \\
& \sum_{i=1}^{k} \beta_{5 i} \Delta L C P I_{t-1}+\phi_{1} L G D_{t-1}+\phi_{2} L G E X P_{t-1}+\phi_{3} L G D P_{t-1}+\phi_{4} L R I N T_{t-1}+\phi_{5} L C P I_{t-1}+\varepsilon_{t}
\end{aligned}
$$

Where $\Delta$ LGD denotes the natural logarithm of government debt at time ( $\mathrm{t}$ ), followed by $\triangle$ LGDP, which denotes the natural logarithm of gross domestic product at a time $(\mathrm{t}), \triangle$ GEXP symbolises the natural logarithm of government expenditure at a time $(\mathrm{t})$, while $\triangle \mathrm{LRINT}$ denotes the natural logarithm of real interest rates at a time $(\mathrm{t})$ and $\triangle \mathrm{LCPI}$ symbolises the natural logarithm of inflation at a time $(\mathrm{t})$. Furthermore, the intercept and the number of lags used are denoted by $\alpha 0$ and $n$, respectively. The short-run dynamics are represented by $\beta 1$ to $\beta 6$, 
followed by the long-run relationship, which is denoted by $\phi 1$ to $\phi 6$, while the error term is represented by $\epsilon$.

In order to investigate a cointegration relationship between the variables, the null hypothesis (no cointegration) and the alternative hypothesis (cointegration) are formulated below:

$$
\begin{aligned}
& H_{0}: \beta_{1}=\beta_{2}=\beta_{3}=\beta_{4}=0 \\
& H_{1}: \beta_{1} \neq \beta_{2} \neq \beta_{3} \neq \beta_{4} \neq 0
\end{aligned}
$$

Making use of the Wald f-test, the bounds test is utilised to test the two hypotheses indicated above, where the estimates of the f-values and critical values from the Persaran et al. (2001) table were compared. When the f-value is greater than the critical value, this will imply that the null hypothesis is rejected, concluding that a long-run relationship between the variables exists. Furthermore, when the f-value is lower than the critical value, this will imply that the null hypothesis is not rejected, and therefore we can conclude that a long-run relationship between the variables does not exist, and therefore there is no cointegration. However, at a point where the f-value lies between the upper and lower critical value, Persaran et al. (2001) assert that this will indicate that the results obtained are inconclusive. After testing for the presence of cointegration, the next step is to estimate the error correction model. When the variables are cointegrated, the error correction equation will be adapted in the following manner:

$$
\begin{aligned}
& \Delta L G D_{t}=\alpha_{0}+\sum_{i=1}^{n} \beta_{1 i} \Delta L G D_{t-i}+\sum_{i=1}^{n} \beta_{2 i} \Delta L G E X P_{t-i}+\sum_{i=1}^{n} \beta_{3 i} \Delta G D P_{t-i}+\sum_{i=1}^{n} \beta_{4 i} \Delta L R I N T_{t-i} \\
& +\sum_{i=1}^{n} \beta_{5 i} \Delta L C P I+\delta E C T_{t-1}+\varepsilon_{t}
\end{aligned}
$$

In order to measure the speed of adjustment towards long-run equilibrium, the error correction term and its coefficient are represented by ECT and $\delta$, respectively. Furthermore, in order to determine the optimal number of lags, this study made use of the Schwarz Bayesian information criterion, as this criterion, according to Brooks (2014), provides precise results irrespective of the sample size utilised in the analysis. Furthermore, in order to check the reliability and accuracy of the model utilised, diagnostic and stability tests will be conducted. Making use of Eviews 9 software, the study conducts the empirical analysis by following the following steps; firstly, the augmented dickey fuller (ADF) and Phillips Perron (PP) unit root test were utilised to determine the order of 
INTERNATIONAL JOURNAL OF eBUSINESS AND eGOVERNMENT STUDIES

Vol 11, No 1, 2019 ISSN: 2146-0744 (Online)

integration of the variables. Secondly, the long-run relationship between the variables was evaluated. Thirdly, the error correction model was estimated. Lastly, the study further conducted the normality, stability, serial correlation, Ramsey RESET test and heteroscedasticity.

\section{RESULTS AND DISCUSSIONS}

\subsection{Correlation analysis}

The Pearson correlation analysis is conducted in order to determine the strength and association between the variables utilised. The correlation coefficient (r) should lie between the range -1 and +1 . As indicated by the study of Ahlgren et al. (2003), if the correlation coefficient is closer to zero, a strong association between the variables is observed, and if the correlation coefficient is closer to one, a strong association is observed between the variables. This study follows the correlation coefficient guideline from Evan (1996), which is summarised in the following manner: 00-0.19- 'very weak', 0.20-0.39- 'weak', 0.40-0.59'moderate', 0.60-0.79 'strong', 0.80-1.0 'very strong'. The results of the correlation test are presented in Table 1 below:

Table 1: Pearson's correlation coefficients

\begin{tabular}{|c|c|c|c|c|c|}
\hline & LGD & LGEXP & GDP & LRINT & LCPI \\
\hline LGD & 1.000000 & & & & \\
\hline LGEXP & $0.480122 * *$ & 1.000000 & & & \\
\hline GDP & -0.345750 & $-0.446437^{* *}$ & 1.000000 & & \\
\hline LRINT & 0.156565 & -0.365594 & -0.79580 & 1.000000 & \\
\hline \multicolumn{6}{|c|}{ Note: $* *$ denotes $5 \%$ level of significance } \\
\hline \multicolumn{6}{|c|}{$\begin{array}{l}\text { The correlation between LGD and LGEXP is statistically significant at the 5\% } \\
\text { level of significance. However, the correlation between LGD and the other } \\
\text { variables (GDP, LRINT and LCPI) is not significant. Furthermore, the correlation } \\
\text { between LGEXP and GDP is statistically significant at the } 5 \% \text { level of } \\
\text { significance. However, the correlation between LGEXP and the variables (LRINT } \\
\text { and LCPI) is not significant. This is followed by a non-significant correlation } \\
\text { between LRINT and LCPI. Furthermore, a moderate association is observed } \\
\text { between the variables LGD and LGEXP followed by LGEXP and GDP. } \\
\text { Moreover, a weak association between LGD and the variables (GDP, LRINT and }\end{array}$} \\
\hline
\end{tabular}


INTERNATIONAL JOURNAL OF eBUSINESS AND eGOVERNMENT STUDIES

Vol 11, No 1, 2019 ISSN: 2146-0744 (Online)

LCPI) is observed, followed by a weak association between LEXP and the variables (LRINT and LCPI), followed by a weak association between GDP and LCPI, and lastly a weak association is observed between LRINT and LCPI. The results further indicate that the correlation between LRINT and LCPI is the weakest, while the correlation between GDP and LRINT is the strongest compared to the other variables.

\subsection{Unit root test}

This study made use of the ADF and the PP unit root test in order to test the order of integration of the variables. As can be seen in Table 2, the results indicate that all variables are stationary either at $\mathrm{I}(0)$ or at $\mathrm{I}(1)$.

Table 2: Unit root test

\begin{tabular}{llllll}
\hline Variable & ADF & & PP & & $\begin{array}{c}\text { Order of } \\
\text { integration }\end{array}$ \\
\hline LGD & t-stats & p-value & t-stats & p-value & \\
\hline LGEXP & -2.186307 & $0.0306^{* *}$ & -2.186307 & $0.0306^{* *}$ & $\mathrm{I}(1)$ \\
\hline GDP & -3.993554 & $0.0004^{*}$ & -4.041716 & $0.0003^{*}$ & $\mathrm{I}(1)$ \\
\hline LCPI & -2.326298 & $0.0223^{* *}$ & -2.245289 & $0.0268^{* *}$ & $\mathrm{I}(0)$ \\
\hline LRINT & -4.376926 & $0.0032^{*}$ & -7.008209 & $0.0000^{*}$ & $\mathrm{I}(1)$ \\
\hline
\end{tabular}

Note: $*$ denotes significance at $1 \%, * *$ denotes significance at $5 \%$.

\subsection{Model selection}

Making use of the Schwarz information criteria, the optimal number of lags utilised by this study is 1 . Therefore, the model chosen is the ARDL $(1,1,1,0,0)$ model.

\subsection{Bounds testing and long-run analysis}

The results of the bounds test are summarised in Table 3 below:

Table 3: ARDL bounds test

\section{Dependent variable: LGD}


INTERNATIONAL JOURNAL OF EBUSINESS AND eGOVERNMENT STUDIES

Vol 11, No 1, 2019 ISSN: 2146-0744 (Online)

\begin{tabular}{lll}
\hline Critical value bounds & I(0) Bound & I(1) Bound \\
\hline $\mathbf{1 0 \%}$ & 2.2 & 3.09 \\
\hline $\mathbf{5 \%}$ & 2.56 & 3.49 \\
\hline $\mathbf{1 \%}$ & 3.29 & 4.37 \\
\hline Conclusion & Cointegration & \\
\hline
\end{tabular}

The null hypothesis of no long-run relationship is rejected, as the F-value, 7.699539, lies above the upper bound critical values at all levels of significance. A long-run relationship between government debt and its key drivers is therefore evident. The long-run relationship between government debt and its key drivers arises from the fact that the government needs capital in order to conduct activities and fulfil its obligations. In most cases, the government is running at a deficit. This, therefore, fuels the need to borrow, not forgetting that the government is liable for debt service costs, and ultimately the economy suffers as money that should have been invested into domestic capital and profit forming activates is used to service the debt. The long-run relationship is also observed by Brini et al. (2015) and Wrega (2015). Because there is a long-run relationship between the variables, the long-run results are summarised by equation 3 below.

\section{Long-run equation:}

\section{$L G D=6.020889 L G E X P-0.043570 G D P-0.086676 L C P I+0.099521 L R I N T$ $-15.9949$}

A positive, significant relationship between government debt and government expenditure exists. A one percent increase in government expenditure will on average result in a 6.02 percent increase in government debt. An analysis of government spending in South Africa reveals that the increase in spending has been driven by consumption spending as the public sector wage bill continues to rise instead of investment activities. Furthermore, the expenditure on social welfare has continuously increased in an effort to relieve the poor from the triple challenges of poverty, inequality and unemployment, which continue to affect the country. This puts a major strain on government debt, especially if unemployment and growth levels continue to be low. These findings are supported by Mah et al. (2013) and Milu (1998).

A negative significant relationship between government debt and economic growth is observed, implying that a one percent increase in economic growth will on average result in a 0.04 percent decrease in government debt. The findings of 
this study are in line with the Classical school thought on the view that government debt may be unproductive and wasteful (Smith, 1776), especially if it is on non-productive services, which will have negative effects on economic growth. The study of Kumar and Woo (2010) mirrors the findings of this study.

A negative, insignificant relationship was observed between government debt and inflation. This suggests that a one percent increase in inflation will on average result in a 0.08 percent decrease in government debt. These results are consistent with the findings of Warega (2012) and Forslund et al. (2011), who also found a negative association between inflation and government debt. This is because inflation reduces the true value of money, as inflation benefits the borrower (debtor) at the expense of the creditor (lender), as it reduces the value of the debt that South Africa would have to pay back. In this manner, the government tends to benefit at the expense of the private sector since it is one of the biggest debtors. These findings are advocated by the study of Akitoby et al. (2014), who indicate that even though inflation alone can hardly solve the problem of debt, an increase in inflation could help with debt reduction. .

A positive, insignificant relationship between government debt and interest rate was also observed. A one percent increase in interest rates will on average result in a 0.09 percent decrease in the government debt. The findings of this study are in agreement with the study of Karanja (2013), Engen and Hubbard (2004), and Juma (2010), who found a positive relationship between these two variables. The positive relationship between interest rates and government debt lies behind the fact that as interest rates increase, private investment is affected through the 'crowding-out' effect, which ultimately hinders economic growth, and leads to a reduced amount of tax revenue collected by government. This will further lead to increased government deficits and ultimately the government will have to borrow, and therefore an increase in government debt.

\subsection{Short-run relationship and error correction model}

The error correction model findings are summarised in Table 4 below.

Table 4: Short-run and error correction results

\begin{tabular}{lllll}
\hline Variable & Coefficient & Std. error & t-statistic & P-value \\
\hline D(LGEXP) & 1.013891 & 0.261589 & 3.875889 & $0.0013^{* *}$ \\
\hline D(GDP) & 0.011253 & 0.003988 & 2.821448 & $0.0123^{* *}$ \\
\hline D(LCPI) & -0.005708 & 0.016975 & -0.336246 & 0.7411 \\
\hline D(LRINT) & 0.007633 & 0.020046 & 0.380779 & 0.7084 \\
\hline
\end{tabular}


INTERNATIONAL JOURNAL OF eBUSINESS AND eGOVERNMENT STUDIES

Vol 11, No 1, 2019 ISSN: 2146-0744 (Online)

\begin{tabular}{l} 
CointEq(-1) $-0.130657 \quad 0.017446 \quad-7.489299 \quad 0.0000$ \\
\hline Note: $*$ denotes $5 \%$ level of significance. \\
The results indicate that government debt is stimulated in the short run by \\
expenditure and economic growth. The results also show that inflation and interest \\
rates are statistically insignificant, therefore suggesting that inflation and interest \\
rates have no short-run impact on government debt. The error correction term is \\
negative and statistically significant, indicating that the speed of adjustment is \\
satisfactory with a coefficient of -0.130657 and a probability value 0.0000. \\
Moreover, the coefficient of 0.201243 indicates that approximately 13 percent of \\
any disequilibrium is corrected each year; furthermore, this implies that it will \\
take approximately one year for changes in government debt to affect its key \\
drivers.
\end{tabular}

\subsection{Diagnostics and stability results}

The study further conducted diagnostics and stability tests in order to determine the legitimacy of the model used. The results reveal that the series utilised is normally distributed, there is no serial correlation, there is no heteroscedasticity, there are no misspecification errors and the model is stable. This, therefore, indicates that all econometric assumptions were met by the $\operatorname{ARDL}(1,1,1,0,0)$ model.

\section{CONCLUSIONS AND RECOMMENDATIONS}

Over-borrowing and high government debts undermine growth and development. This has been the case in South Africa, as, despite the surge in government debt, the country still faces challenges of low growth, unemployment and inequality. The findings of the ARDL model found that there was a positive relationship between government debt and government expenditure. This, combined with less than three percent growth rates, shows that South Africa's debt has been used on non-productive spending, further fuelling low economic growth and the budget deficit. A positive relationship was also found between government debt and interest rates, implying that increasing interest rates meant higher debt servicing costs, and vice versa. A negative relationship was observed between government debt and real GDP, indicating that a growing economy makes it possible to reduce debt levels, and vice versa. This shows that although South Africa has a favourable debt structure, the fact that debt levels have been increasing over the years questions the country's debt management capacity and the sustainability of the situation thereof. Therefore, there is a need to reduce the gap between debt 
INTERNATIONAL JOURNAL OF eBUSINESS AND eGOVERNMENT STUDIES

Vol 11, No 1, 2019 ISSN: 2146-0744 (Online)

levels and budget deficit. A growing economy measures a country's ability to repay debt; therefore, there should be an improvement in the country's productive capacity, which is going to require a shift from consumption (non-productive) expenditure to capital expenditure. Spending on non-performing SOE bailouts can be avoided through the opening for competition in the problematic SOE sectors, such as the electricity industry. Given that research shows that government's current spending has a tendency to increase more compared to capital spending in years that elections take place, the real challenge for the South African government is to ensure that populist policies do not lead to increased government current spending as the country approaches the 2019 national elections and also does not add to the already growing government debt.

\section{REFERENCE LIST}

Afonso, A. (2003). Understanding the Determinants of Sovereign Debt Ratings: Evidence for the Two Leading Agencies. Journal of Economics and Finance, 27(1).

Ahlgren, P.; Jarneving, B. \& Rousseau, R. (2003). Requirements for a cocitation similarity measure, with special reference to Pearson's correlation coefficient. Journal of the American Society for Information Science and Technology, 54(6), pp. 550-560.

Akitoby, M.B., Komatsuzaki, M.T., \& Binder, M. (2014). Inflation and public debt reversals in the G7 Countries. IMF Working Paper 14-96. Washington DC: IMF.

Barro, R.J. (1979). On the Determination of the Public Debt. Journal of Political Economy, 57: 940-71.

Battaile, B., Hernandez, F.L. \& Norambuena, V. (2015). Debt Sustainability in Sub-Saharan Africa: Unraveling Country-Specific Risks. World Bank Policy Research Working Paper 7523. Washington DC: World Bank.

Belguith, O. \& Omrane, H. (2017). Macroeconomic determinants of public debt growth: A case study for Tunisia. Theoretical and Applied Economics, 24(4): 161-168.

Brandmeir, K., Grimm, M., Heise, M. \& Holzhausen, A. (2017). Allianz Global Wealth Report 2017.

https://www.allianz.com/v 1506497732000/media/press/document/AGWR_17Report_EN.pdf Accessed 2018/06/10 
INTERNATIONAL JOURNAL OF EBUSINESS AND EGOVERNMENT STUDIES

Vol 11, No 1, 2019 ISSN: 2146-0744 (Online)

Brini, R., Farrouhk, A. and Jemmali, H. (2015). Public debt and economic growth in Tunisia: A re-examination. Advances in Economics and Business, 4(11):584590.

Brooks, C. (2014). Introductory econometrics for finance. 3rd ed. Cambridge: Cambridge University Press.

Clements, B., Bhattacharya, R. \& Nguyen, T.Q. (2003). External Debt, Public Investment, and Growth in Low-Income Countries. IMF Working Paper 249. Washington DC: IMF

Crivelli, E., Gupta, S. \& Correa-Caro, C. (2016). Fragmented Politics and Public Debt. IMF Working Paper 16/190. Washington DC: IMF.

Engen, E. \& Hubbard, R.G. (2004). Federal government debts and interest rates. NBER working paper 10681. National Bureau of Economic Research.

Evans, J. D. (1996). Straightforward statistics for the behavioural sciences. Pacific Grove, CA: Brooks/Cole Publishing.

Fall, F., Hoeller, P., Fournier, J.M. \& Bloch, D. (2015). Prudent debt targets and fiscal frameworks. OECD Economic Policy Papers 15. Paris: OECD

Forslund, K., Lima, L. \& Panizza, U. (2011). The determinants of the composition of public debt in developing and emerging market countries. Review of Development Finance, 1(3-4): 207-222.

Fourie, C.V. \& Burger, P. (2010). How to think and reason in macroeconomics. 3rd ed. Claremont: Juta.

Friedman, B.M. (1978). Crowding out or crowding in? The economic consequences of financing government deficits. Cambridge, MA: National Bureau of Economic Research.

Gruber, J. (2011). Public Finance and Public Policy. New York: Worth publishers.

Henisz W. J. (2000). The Institutional Environment for Economic Growth. Economics and Politics, 12(1).

Holtfrerich, C; Feld, L; Heun, W et al. (2016). Government debt: causes, effects and limits. Berlin-Brandenburg Academy of Sciences and Humanities. Berlin, 76 pages. 
INTERNATIONAL JOURNAL OF EBUSINESS AND eGOVERNMENT STUDIES

Vol 11, No 1, 2019 ISSN: 2146-0744 (Online)

Johansen, S. \& Juselius, K. 1990. Maximum likelihood estimation and inference on cointegration with applications to the demand for money. Oxford Bulletin of Economics and Statistics, 52:169-210.

Juma, B. (2010). Domestic debt and private investment in Kenya 1963-2009. Masters Dissertation. Nairobi: University of Nairobi.

Kalaja, E. \& Vokshi, A. (2015). Public debt determinants in Albania. Journal of Process Management - New Technologies, International, 3(4).

Karanja, K.G. (2013). Relationship between domestic debt and interest rate in Kenya. Masters dissertation. Nairobi: University of Nairobi.

Keynes, J. M. (1937). The general theory of employment. The Quarterly Journal of Economics, 51, 209-223.

Kharusi, S.A, \& Ada, M.S. (2018). External debt and economic growth: The case of emerging economy. Journal of economic integration, 33(1):1141-1157

Kumar, M.S. \& Woo, J. (2010). Public Debt and Growth. IMF Working Paper 174. Washington DC: IMF.

Mah, J; Petersen, J. M; Miruka, C \& Peterson, M. A. (2013). The impact of government expenditure on the Greek government debt: An econometric analysis. Mediterranean Journal of Social Sciences, 4(3):2039-2117.

Mellet, A. (2012). A critical analysis of South African economic policy. $\mathrm{PhD}$ Thesis. Vanderbijlpark - North-West University.

Mendoza, E.G. \& Oviedo, P.M. (2004). Public debt, fiscal solvency and macroeconomic uncertainty in Latin America: The cases of Brazil, Colombia, Costa Rica and Mexico. Economia Mexicana NUEVA EPOCA, 0(2): 133-173.

Milu, M. (1998). Revenue, public spending and fiscal deficits in Kenya: An econometric analysis 1965-1996. Masters Dissertation. Nairobi: University of Nairobi.

Natalia, C. (2006). Influence of economic and political factors on the level of government debt: case of transition countries. Masters dissertation. Ukraine: National University "Kyiv-Mohyla Academy".

National Treasury. (2018). Budget Review. Pretoria: Government Printer. 
INTERNATIONAL JOURNAL OF EBUSINESS AND eGOVERNMENT STUDIES

Vol 11, No 1, 2019 ISSN: 2146-0744 (Online)

OECD (2017). Economic Surveys South Africa: Overview.

http://www.oecd.org/eco/surveys/economic-survey-south-africa.htm Accessed $\underline{2018 / 06 / 12}$

Perkins, D.H, Radelet, S. \& Lindauer, D.L. (2006). Economics of Development. $6^{\text {th }}$ ed. New York: Norton \& Company.

Pesaran, M.H.; Shin, Y. \& Smith, R.J. (2001). Bounds testing approaches to the analysis of level relationships. Journal of Applied Econometrics, 16(3), pp. 289326.

Pirtea, M.G., Nicolescu, A.C. \& Mota, P.R. (2013). An empirical study on public debt's determinants: evidence from Romania. Transylvanian Review of Administrative Sciences, 38E: 144-157.

Reinhart, C.M. \& Rogoff, K.S. (2010). Growth in a time of debt. American Economic Review, 100(2):573-78.

Shah, A. (2007). Third World Debt Undermines Development.

http://www.globalissues.org/issue/28/third-world-debt-undermines-development Accessed 2018/04/19

Smith, A. (1776). An Inquiry into the Nature and Causes of the Wealth of Nations, Book V, Chapter III: "Of Public Debt". In R. H. Campbell \& Skinner, A. (Ed.), Glasgow Edition of the Works and Correspondence of Adam Smith (vol. II). Indianapolis: Liberty Fund.

Swamy, V. (2015). Government Debt and its Macroeconomic Determinants: An Empirical Investigation. Munich Personal Repec Archive (MPRA) Paper 64106.

Van Cauwenbergh, L. \& Laleman, J.P (2018). Rapid public debt build-up in subSaharan Africa. https://www.credendo.com/country-news/rapid-public-debtbuild-sub-saharan-africa Accessed 2018/06/13

Vollgraaff, R. \& Cohen, M. (2017). The problem of SA's mounting debt. Bloomberg. https://www.fin24.com/Budget/Budget-and-Economy/the-problemof-sas-mounting-debt-20171025 Accessed 2018/09/05

Von Stein, L. (1871). Textbook of public finance as the basis for lectures and selfstudy. $2^{\text {nd }}$ ed. Leipzig: Ed. Brockhaus.

Warega, J.A. (2012). The relationship between government budget deficit and domestic debt in Kenya. Masters dissertation. Nairobi: University of Nairobi. 
INTERNATIONAL JOURNAL OF EBUSINESS AND EGOVERNMENT STUDIES

Vol 11, No 1, 2019 ISSN: 2146-0744 (Online)

WEF (World Economic Forum). (2014). Global Risks 2014. 9th ed. Geneva.

World Bank. (2013). International Debt Statistics. Washington, DC: World Bank. 